\title{
Building students' knowledge one click at a time
}

\section{Quentin Vicens}

Faculty Developer in Science Teaching Qvicens consulting, 26 avenue Romain Rolland, 06100 Nice, France

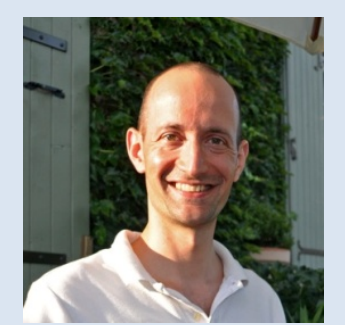




\section{Abstract}

Clickers are a popular type of audience response system that enliven lectures and make them engaging. Clickers give instructors access to students' thinking and reasoning in real time. But how should one teach using clickers? How could one promote effective learning even in large classes? What kind of questions could be asked? This review aims to answer these three key questions with a particular focus on practical tips and helpful resources such as 'how-to' guides for implementation. Finally, this review also highlights various systems that can be employed to turn mobile devices into learning devices, thereby taking clicker technology and pedagogy to the next level. 


\section{Introduction: On lectures, technology, and learning}

From a technological point of view, lecturing has dramatically evolved in the past 50 years. Presentations supported by projector slides and overheads have supplanted most chalk talks, until they in turn became replaced by lectures prepared using presentation software, particularly as laptop computers became more prevalent. With the advent of wireless networks, presentations started incorporating movies, podcasts, and could be entirely hosted online (see for example Prezi (Somlai-Fischer, Halacsy, \& Arvai, 2009) and Google Drive (Google, 2012)). So, technology has made its way quite rapidly into education.

Yet, from an instructional point of view, the practice of lecturing has evolved very little - if at all. Today, a lecture still principally relies on a professor talking to a passive audience for a rather long period of time, typically 45 minutes or more. Although lecturing as a mode of transfer of information has worked well for the past 2,000 years, it has become rather obsolete at a time when information is available to everyone through books, the Internet and social media. Why ask students to come to a crowded auditorium to listen to a presentation they could comfortably watch anywhere on their smart phone (Lambert, 2012)?

Well, class time is class time! For an audience, listening to experts often remains fascinating, and even necessary. But the problem with a lecturesonly pedagogy is that it leaves very little room, if any, for interaction with those same experts in order to guide the process of building knowledge.

Unfortunately, while it is true that enthusiasm and passion for a subject may be contagious, this is not the case with knowledge. Knowledge still needs to be constructed, through a process of integration of new concepts to prior knowledge (Biggs, 2007; Bransford, Brown, \& Cocking, 2000). The most common form of learning therefore represents not just the transfer of information, but also the process of assimilation of that information (Illeris, 2003; Mazur, 2011). As Tom Cech and Donald Kennedy phrased it, "Learning is not a spectator sport" (Cech \& Kennedy, 2005). In fact, we have known for quite some time - at least since the work of Ralph Tyler in the middle of the 20th century (Tyler, 1949) - that students learn from doing and not from hearing. How then do we make lectures more about doing and less about hearing?

\section{Clickers as a technology to promote learning}

A popular solution to engage students is audience response systems, which are more widely known as "clickers". Clickers are used by over half a million university students in the US only (Steinberg, 2010). In Europe, clickers have been broadly adopted in Spain (UN, 2010) and the UK, which 
in October 2011 hosted the first European conference for clicker users organized by one of the leaders in clicker technology (TT, 2011b). Worldwide, many lecturers have expressed how clickers almost work "like magic": students get overtly engaged with one another, with their lecturer, and with their own learning process. On their end, students praise the opportunity for taking a break from the lecture, for sharing with their classmates, for voting in total anonymity, and for seeing how they perform in comparison with the rest of the class. Overall, clickers are thus typically appreciated on both sides (Knight \& Wood, 2005).

The experience of introducing clickers at the Faculty of Science and Technology at Aarhus University echoes these positive experiences. Over the past three years, an increasing number — now reaching 50 - of faculty members from six departments have incorporated clickers into their teaching. See Figure 1 below. Their typical experience has been that "students are activated and gain a deeper understanding of problems", or that through clickers "everyone is involved", particularly when trying "to communicate with some 200 students" (comments obtained by anonymous feedback from 25 lecturers who used clickers, collected in October 2011¹). Clickers are only gaining in popularity among our faculty and more clickers as well as mobile learning solutions are regularly purchased to keep up with the demands.
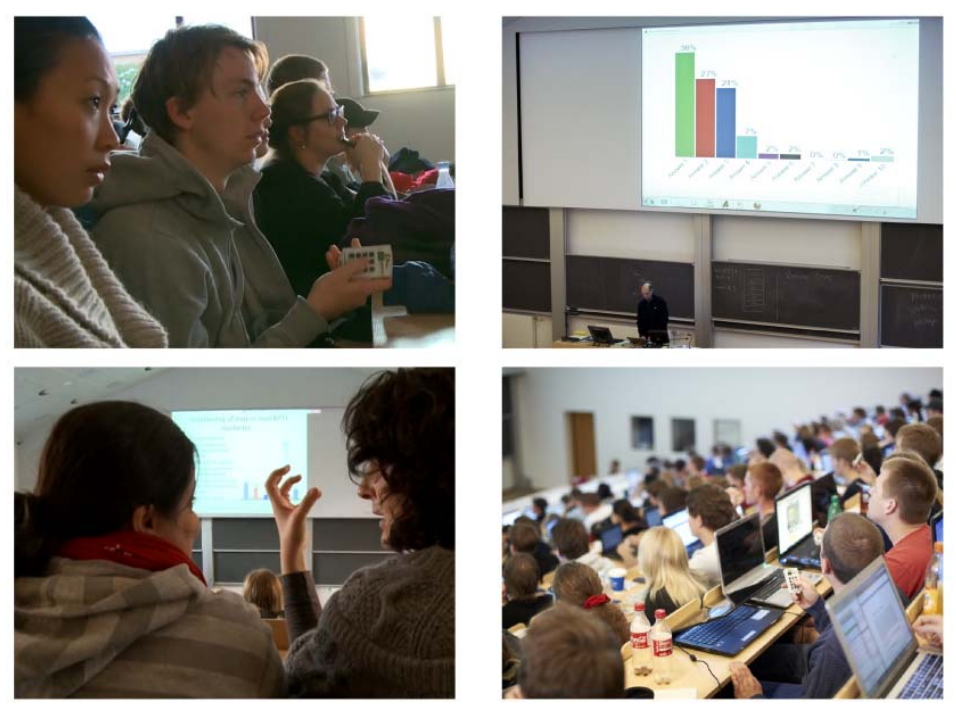

Figure 1: Clickers used in two large classes (left: biochemistry; right: computer science) at the Faculty of Science and Technology at Aarhus University, Denmark.

${ }^{1}$ An interview of D. Brodersen, a lecturer from the Department of Molecular Biology and Genetics who started using clickers in 2010, can also be watched online, where he describes his experience using clickers in the classroom (SML, 2010). 
Students have also recognized how clickers have improved their learning experience. In a survey conducted in late 2010 by D. Brodersen, M. Etzerodt and J. Rasmussen after they had introduced clickers into an 'Advanced biochemistry' course, clickers and discussions during clicker questions were selected by $29 \%$ and $16 \%$ of students, respectively $(n=67)$, as the learning tool that was most helpful to them (Brodersen, Etzerodt, \& Rasmussen, 2012). This is in comparison to only $13 \%$ of students choosing the online availability of lecture slides on the course website as important for their learning, and tools such as group work (13\%), quizzes on the course website (11\%), and threaded organization of the online resources (7\%). In another large class (Physics), students most commonly reported that "clickers keep us active and awake" and that "clickers are an excellent variation and make lectures more lively", which some students conveyed would help them "keep their nose to the grindstone" (0. Bjælde, Department of Physics and Astronomy, personal communication). So in Denmark as well, clickers have been praised by faculty and students alike for helping to enhance the student learning experience.

Now, this "magic" does not operate on its own. Effort needs to be placed into developing an overall approach to teaching that promotes student learning, for example, through establishing clear learning goals, precise ways to assess attainment of these goals, and appropriate teaching methods for reaching these goals (Handelsman, Miller, \& Pfund, 2007; Wieman, 2007). Within that context, clickers represent a powerful tool to enhance interactions, develop critical thinking skills, and promote learning. Box 1 on p. 14 gives a list of tips on how to use clickers and what to be wary of. Let's explore further some of the most popular practices for using clickers in the classroom.

\section{Simple vote, Think-Pair-Share, and Peer Instruction: Three strategies for using clickers in class}

Asking your students to answer one of your typical in-class questions anonymously using clickers may be the most intuitive way to use clickers. Such questions can be asked spontaneously and are typically polls, opinion surveys, or recall from material presented previously. See Figure 2 below. The format of the answers would be a simple yes/no or would offer a selection of possible answers. For examples of clicker questions, see Box 2 on p. 19. Using clickers to collect votes and instantly reveal the distribution of answers is an effective way to know your audience, to launch a discussion, and/or to introduce the next subject. You will get feedback from all students, instead of being met with blank stares and a disarming silence, until the same few "Hermione Granger" students who always know the answer or have an opinion raise their hand... 
Think-Pair-Share and Peer Instruction are two other strategies for using clickers, but with a greater learning enhancement capacity when compared to the simple vote described above. Both methodologies work well to evaluate and develop conceptual understanding and critical thinking. See Figure 2 below.

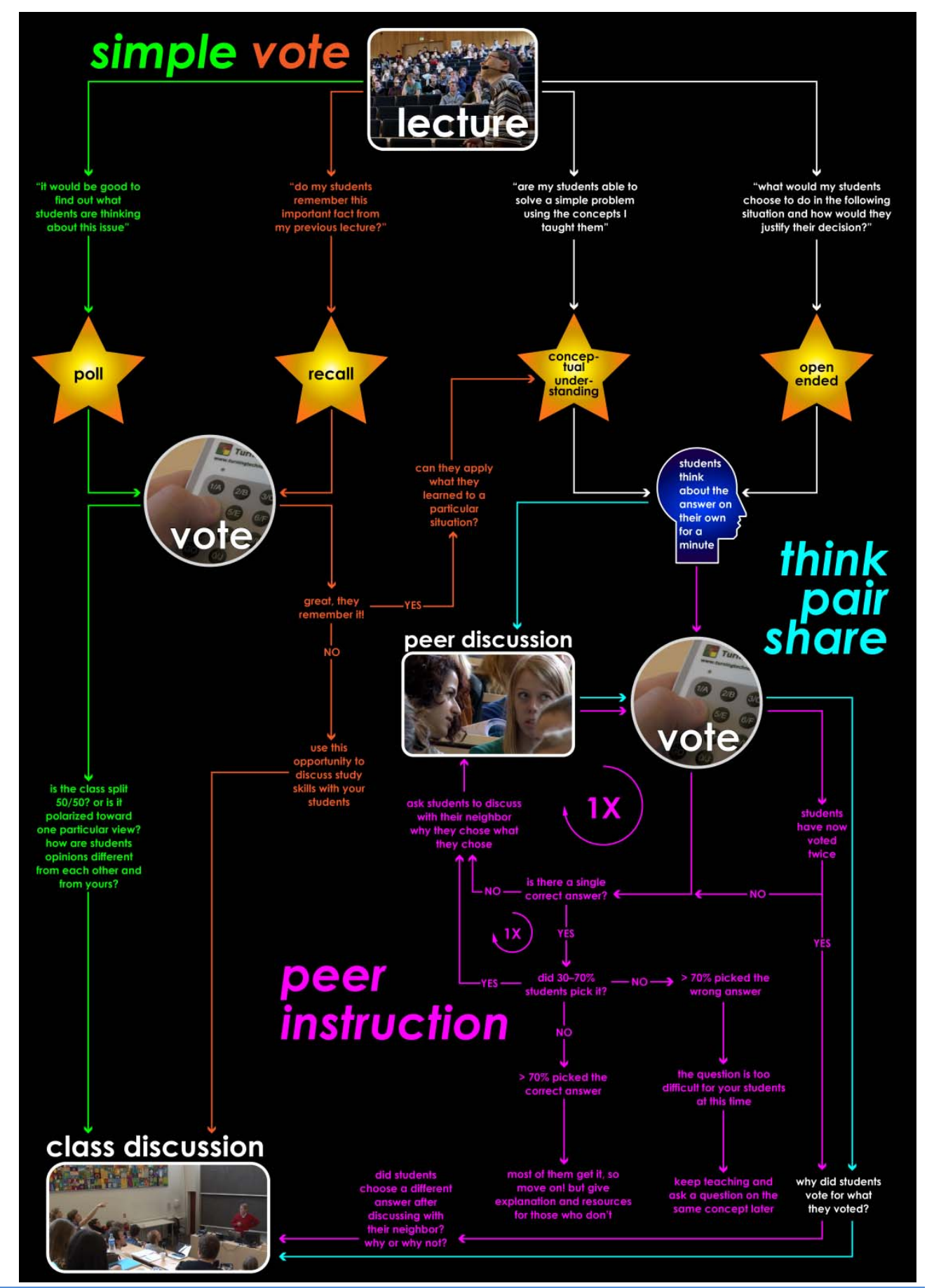

Figure 2: Flow-chart suggesting examples of scenarios for interrupting lectures with clicker questions. The infographic underlines the interconnectedness between the Simple Vote, ThinkPair-Share and Peer Instruction. It also relates these strategies to the types of clicker questions shown in Box 1. 
With Think-Pair-Share, the main addition to the simple vote is that students are given some time to think on their own which answer they would pick. After such a reflection time, students are invited to pair with a neighbor to exchange their answer and to discuss their reasoning. Finally, students get to share their answers with the class (Jones, 2012; Lyman, 1981). Originally, the last step would require the instructor to call on all or several pairs of students in turn. But, when using clickers, the final step can be replaced by an anonymous individual vote followed by a whole-class discussion. The lecturer may then ask for feedback from pairs of students according to the distribution of answers: "Those who answered ' $B$ ', could you tell us why you chose B?"; or "Even if you did not answer A, why might someone want to answer A? Why is A tempting?" (also see suggestions in Box 1). Such discussions help reveal students' prior knowledge and potential misconceptions and makes for an opportunity to replace wrong by correct reasoning. Finally, a way to check how well students learned in the process could consist of asking them to solve a problem relating to the same concept but that would seem different to them (e.g., a question about a certain genetic disease in flies is turned into one in fish) (Levesque, 2011; Smith et al., 2009).

This strategy has the advantage of having a simple and flexible, but beneficial structure to promote learning. Specifically, Think-Pair-Share is amenable to question types that can be designed to meet intended learning outcomes related to conceptual understanding and critical thinking (See Box 2 on p. 19). Pausing the lecture and inviting students to think and reflect when they first see the clicker question is important for assimilation of material covered in the preceding lecture and for knowledge construction. Finally, the discussion with the neighbor is valuable because students are more likely to understand why they are wrong when hearing the explanation from a classmate who just learned the same concept recently, rather than "from the professor in front of the class" who learned it a long time ago (Hanford, 2012).

The third strategy discussed here, Peer Instruction, was developed by Prof. Eric Mazur at Harvard University (Mazur, 1997, 2008). It follows the main steps of the Think-Pair-Share technique, but with a major difference: Students are also asked to vote right after having thought on their own (See Figure 2 above and Box 1 on p. 14). However, the lecturer may decide to hide the results of that vote before asking students to discuss and vote again, because displaying the distribution of answers from the first vote may bias the second vote (Perez et al., 2010). Then, after the first vote, students are instructed to turn to their neighbor and try to convince that person of their answer, similarly as during Think-Pair-Share (see Box 1). After the second vote, the lecturer can initiate a whole-class discussion 
similarly as in the Think-Pair-Share strategy. Within Peer Instruction, the student-student discussions in between the two votes have actually been shown to promote learning even if none of the students know the correct answer to begin with (Smith et al., 2009). Such findings suggest that Peer Instruction is a strategy that enhances learning through the benefits of collaboration (Dillenbourg, 1999; Dillenbourg, Baker, Blaye, \& O'Malley, 1996) and through the internal development which is promoted when an individual's views of a particular situation are confronted to the reality of that situation (Buchs, Butera, Mugny, \& Darnon, 2004).

Peer Instruction was developed in response to the observation that Physics students could solve complex problems, but without necessarily understanding the fundamental concepts hidden behind these problems (Hestenes, Wells, \& Swackhamer, 1992; Mazur, 1997). Introducing the first vote in Peer Instruction bolsters the quality of the peer discussion and of the feedback received from students. Significantly, the first vote incites students to commit to an answer before discussing it with a neighbor, which strengthens the quality of the following discussion and the motivation to "get it right" the second time, if need be. Furthermore, the distribution of answers after the first vote should always be visible to the teacher, as it makes for a compass that points to the direction where the class should be going next (see Figure 2 above).

When less than $30 \%$ of the students get the correct answer after the first vote, the question is probably too challenging for students and a peer discussion would not be productive. Conversely, $70 \%$ of the votes for the correct answer the first time indicate that most students get it, which means that the gain from peer discussion would be minimal. Successful questions are therefore questions that are challenging the students to the proper extent, collecting between 30-70\% of correct choices after the first vote (Knight \& Wood, 2005; Lasry, Mazur, \& Watkins, 2008; Mazur, 1997). Within that range, peer discussion is likely to lead to sustainable learning, which results in improvement of problem-solving skills (strategies for writing effective questions are given in Box 2 on p. 19 and in the references therein). But if the answers don't go in the expected direction after peer discussion, the instructor will need to spend more time to help students understand the key concepts (watch how Eric Mazur organizes a Peer Instruction session (HM, 2012)).

Peer instruction is effective to promote learning in a large variety of settings, regardless of the discipline (Crouch, Watkins, Fagen, \& Mazur, 2007). A comparative study showed that students from either a top university or a two-year college who were taught using peer instruction had a better conceptual understanding than students taught using traditional lectures (Lasry, 2008). Eventually, peer instruction is best practiced together with strategies that encourage for example web-based 
homework assignments, as these complementary techniques help the lecturer ensure students cover the basics and have some understanding of the main concepts before coming to class (Crouch \& Mazur, 2000; Mazur \& Watkins, 2009).

\section{Creative and inspirational use of clickers}

In addition to the well-established strategies described above, here is a list of only a few examples of creative uses of clickers at ours and other universities worldwide.

- Tin Tin Su, University of Colorado, Boulder, USA: Clicker questions were used in a small seminar-style biology class of 11 students in order to help ensure these students would read the assigned articles before class. Clicker questions also facilitated peer discussions and helped the professor engage all students in the class (Smith, Trujillo, \& Su, 2011).

- Ditlev Brodersen, Michael Etzerodt, Jan Rasmussen, Aarhus University, Denmark: During exercise sessions, students working in groups wrote clicker questions for other groups in the class. They then asked these questions during their presentation of solutions to homework assignments (Brodersen, 2012; Brodersen, et al., 2012).

- Bill Goffe, State University of New York, Oswego, and the librarians at the University of Dubuque, Iowa, USA: Multiple paths through a PowerPoint presentation were created by students using clicker questions, on a principle similar to that of the "choose your own adventure" type of books (Blog, 2008). This type of conditional branching was facilitated by hyperlinks on slides and/or the possibility to jump from a slide to any other slide by typing the number of that slide on the keyboard (Bruff, 2010).

- Mikel Asensio, Universidad Autónoma de Madrid, Spain: The background knowledge of visitors entering a Spanish archeological museum was assessed using clickers (Wiley, 2012). The subsequent guided tour was tailored to the visitors' prior knowledge in order to maximize learning. Clickers were used again at the end to evaluate how much visitors had learned from the visit.

- Gerth Brodal, Department of Computer Science, Aarhus University, Denmark: Clickers were used to demonstrate the working principle of the PageRank algorithm used by Google for searches on the Internet (Wikipedia, 2012). Students pressed buttons on their clickers according to the roll of a dice, thus mimicking the likelihood that web surfers randomly clicking on hyperlinks will arrive at any particular page. Prior to that experiment, clickers had been reprogrammed to remember not just the last 10, but the last 1000 clicks of each student. The probability results were visualized dynamically on the bar graph of answers compiled by the clicker software (Gerth Brodal, personnal communication). 


\section{Using clickers without using clickers: the advent of mobile learning}

The simple vote, Think-Pair-Share, and Peer Instruction pedagogies work in synergy with clicker technology to promote student learning. But with the spread of portable devices - laptops, smart phones, and tablets-, using remotes dedicated to clicker technology may seem outdated and cumbersome. In fact, lecturers at our Faculty have often reported how carrying 200 clickers around over the course of a semester can be quite tedious. Clickers are also costly, and they tend to disappear, unless students are made responsible for them, for example by paying a fee to receive a clicker from their university, or by buying their own. But setting up this type of booking/selling system for clickers requires departments or universities to set up new administrative services, which is typically not practical and could become costly. Let us explore how mobile devices may represent a cheaper, quicker, but just as valuable means to bringing clickerbased pedagogies to the classroom.

Several clicker-like software and apps that were developed for mobile devices are now available online for anyone to use. For example, Jessica Methot, Assistant Professor at Rutgers University, and Nat Banting, High School Teacher of Mathematics in Saskatchewan, Canada, have described how they used Poll Everywhere (Mull, 2009) in their Management (RU, 2011) and Mathematics (Banting, 2011) classes, respectively. Some professors at the University of Calgary, Canada, have chosen Top Hat Monocle to collect student responses (Coholan, 2011). In all three cases, students could vote using any portable device. Instructors generally found their students were more engaged, and the students enjoyed the possibility of using their phone because "they already own them and don't mind carrying them around" (Coholan, 2011).

Even more "clicker apps" are available. Socrative (Socrative, 2012) and Lecture Tools (Samson, 2012) are two additional user-friendly options, the latter even offering various levels of customization from the least to the most interactive teaching practice, in addition to enabling students to take notes right next to the presentation slides (Machielse, 2011). Another promising solution, Learning Catalytics (Mazur, 2012; Mazur, King, \& Lukoff, 2011), was co-developed by Eric Mazur, the author of Peer Instruction (Mazur, 1997). Original features of the system included a personalized instruction to each student about which neighbor they should turn to for peer discussion, based on a pre-recorded seating chart and the nature of the votes after the first round. The system is also able to collect free responses from students such as curves and drawings made using the tactile screen of a smart phone or a tablet. This feature is particularly appealing when considering that only a limited number of pre-compiled answers can be displayed in a multiple-choice question. The latest update 
includes the possibility to create worksheets and quizzes which students can do from anywhere (LC, 2012), thereby effectively bringing learning beyond the classroom, via mobile devices ${ }^{2}$.

Clicker-based education and mobile technologies are thus joining forces to enhance learning in and out of the classroom. The ability to use mobile devices instead of clickers could bring the costs down substantially. For example, Poll Everywhere is free up to 40 students, and costs $\$ 65 /$ month for 250 students (the price of one clicker is around \$35). However, the spread of this clicker fever is limited by the number of students who own a mobile device and who are willing to use it in class. Earlier this year, two classes at our Faculty of Science and Technology at Aarhus University tested the combination of clickers manufactured by Turning Technologies and their proprietary app for mobile devices, called ResponseWare (TT, 2011a) — students could choose to use either a conventional clicker, or their smart phones. The follow-up survey we organized revealed that between $40-60 \%$ of students didn't have a smart phone and/or didn't wish to bring their laptop to class (based on 59 student responses (Physics class) and 108 student responses (Genetics class); see Figure 3 below). These numbers were in line with that recorded at other universities (Dean, 2011). In addition, students from the Physics class were equally split between those who preferred the clicker app to the clicker, and those who claimed the opposite (a preference for using the smart phone was noted in the Genetics class). Of course the percentage of smart phone/tablet users is expected to rise, but a reasonable threshold at which a class could rely completely on smart phone-based clicker systems has not been reached yet.

However, even if all students possessed a mobile device they could use or would be willing to use in class, technological support for such use could be challenging. 14\% (Physics) and 21\% (Genetics) of the students reported technical issues when using the smart phone-based app to vote (See Figure 3 below). Besides the inevitable bugs of using a relatively new app for smart phones, students reported issues with the network and battery consumption. Consequently, clicker app developers, smart phone manufacturers, and university administrators will need to improve both devices and facilities, so that students would be able to use their phones as clickers for several classes in a row, or charge their phone while in class, and send data without delays via wireless networks.

${ }^{2}$ A workshop on Learning Catalytics given in October 2012 by Eric Mazur at the Université de Lausanne (Switzerland) can be watched online (Mazur, 2012). 
A.

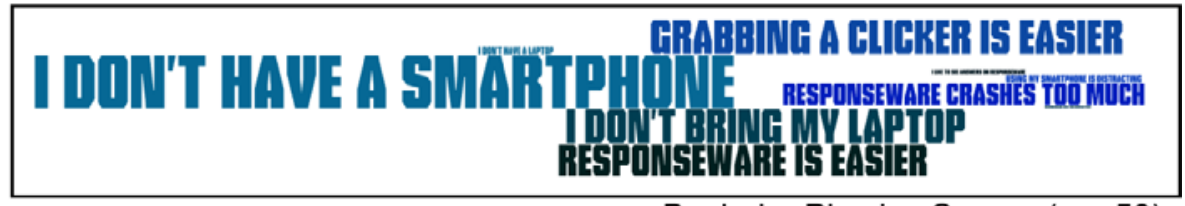

Bachelor Physics Course $(n=59)$

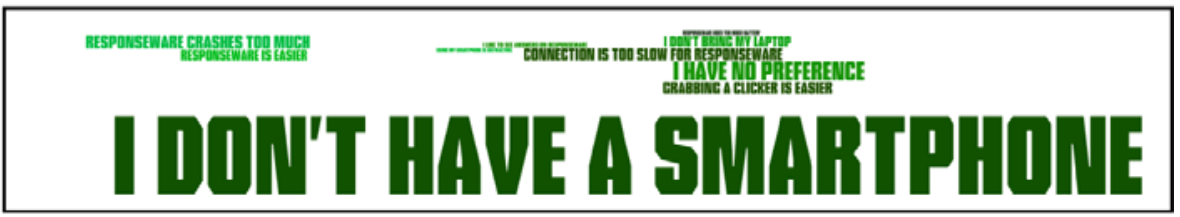

Bachelor Genetics Course $(n=108)$

B.

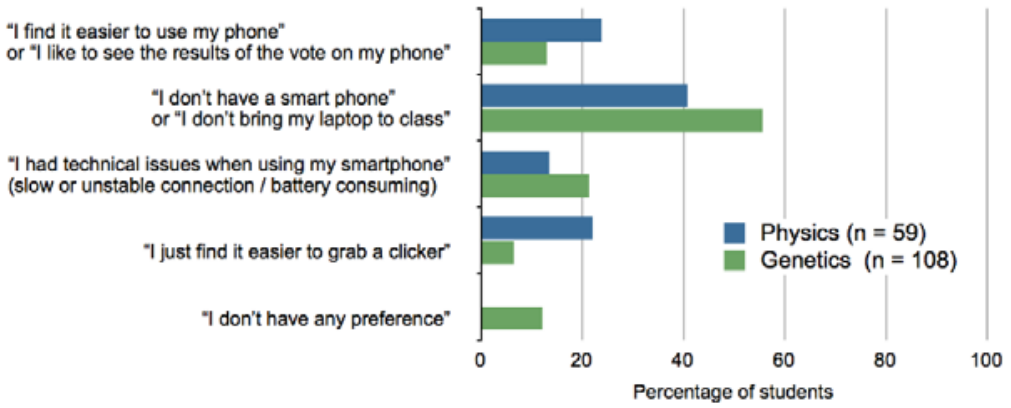

Figure 3: Do students prefer to use a clicker app on their portable device rather than a clicker and why? Student responses from two bachelor introductory courses (Physics and Genetics) at the Faculty of Science and Technology, Aarhus University, Denmark. The clicker app we surveyed was ResponseWare from Turning Technologies. A. Nature and frequency of student responses; The largest the font size, the most common the answer. B. Percentage of students for the five most common responses.

\section{Concluding remarks}

Clicker technology is a powerful asset toward improving education.

Although pedagogies supported by clickers may promote learning to a similar extent than more basic voting techniques such as show of hands or colored cards, (Lasry, 2008; Prather, Slater, Brissenden, \& Forestell, 2008) clickers have several advantages. On the student's side, clickers make voting absolutely anonymous, and the responses are displayed instantly for everyone to see. Pressing a button to vote is also just easy and quite fun. On the instructor's side, having a comprehensive and visually appealing record of all the responses in a class is akin to getting a snapshot of the level of understanding at that particular point in time. Such feedback is essential for guiding follow-up discussions, and should be used to adjust upcoming lectures.

With the advent of mobile devices, clicker apps are now available that help curb clicker management costs, but that also depend on students owning 
such devices. About $50 \%$ of the student population owns a smart phone, which currently limits the use of clicker apps for smart phones to classes where conventional clickers can be used in conjunction with them, or to classes that have a higher concentration of smart phone users. In the long run, "legalizing" the use of mobile devices in higher education - not just authorizing it but also supporting mobile device etiquette- may help universities leap into personalized blended learning (BL, 2012), as such technologies would make student-instructor interactions more frequent and of a higher quality.

\section{Acknowledgements}

I wish to thank Michael Caspersen, the Centre for Science Education, and Aarhus University for support; Henrik Sørensen for providing an openended clicker question; Gerth Brodal and Ole Bjælde for sharing their experience with clickers; Stephanie Chasteen, Ditlev Brodersen, Chrysa Latrick and Michael Caspersen for comments on the manuscript. 


\section{Boxes}

\section{Box 1}

A Dos and Don'ts reference guide for using clickers. ${ }^{3}$

\section{Before class}

\begin{abstract}
Write questions related to the main points of your lectures, for two reasons: 1 . it makes you really aware and focused on what these key points are (SML, 2010); 2. you don't want to waste time writing questions on issues that are not important!
\end{abstract}

\author{
Don't only write clicker \\ questions that are about recall \\ of information. If it is still \\ important to test memory and \\ remembering of facts, place these \\ in a broader context, or include \\ them within a conceptual question \\ (e.g., in order to solve the problem \\ it will be necessary to remember \\ the definitions of the components \\ presented in that problem). Be \\ cautious nonetheless, as such \\ questions may make it difficult to \\ distinguish whether students \\ reason inaccurately or simply \\ don't remember.
}

\footnotetext{
${ }^{3}$ More details and examples of strategies for writing clicker questions and for using clickers can be found in (Beatty, Gerace, Leonard, \& Dufresne, 2006; Bruff, 2009; Suskie, 2009), in this resource guide (Wieman et al., 2009), these quick tips (Duncan, 2008), this video series (CWSEI, 2009b) and more (CWSEI, 2009a) from the joint Science Education Initiatives led by Carl Wieman, or on the blog at PeerInstruction.net (Schell, 2012) and the blog at TheBrokenDam.com (Vicens, 2010).
} 


\begin{tabular}{|c|c|}
\hline Dos & Don'ts \\
\hline $\begin{array}{l}\text { When asking a conceptual } \\
\text { question, introduce common } \\
\text { misconceptions and } \\
\text { commonsense beliefs as wrong } \\
\text { choices (Hestenes, et al., 1992); } \\
\text { they are likely to be picked by a } \\
\text { significant part of the student } \\
\text { population, which will allow you } \\
\text { to reveal and address these } \\
\text { misconceptions during class. You } \\
\text { often know these from experience } \\
\text { or you can find them in student } \\
\text { responses from past exams. }\end{array}$ & $\begin{array}{l}\text { Don't feel bad about spending } \\
\text { time at first to write clicker } \\
\text { questions. Generally, planning for } \\
\text { activities that will enhance student } \\
\text { learning is a better use of your } \\
\text { time than preparing slides that } \\
\text { students will not remember. In the } \\
\text { end, you will also have less lecture } \\
\text { slides to prepare because you will } \\
\text { now spend time on clicker } \\
\text { questions during lectures. }\end{array}$ \\
\hline $\begin{array}{l}\text { Use clicker questions other } \\
\text { professors have created. A } \\
\text { clicker question wiki is now } \\
\text { available for most disciplines } \\
\text { (Lukoff, 2012). You can use these } \\
\text { questions if they fit with your } \\
\text { goals, or modify them, and } \\
\text { perhaps upload your revision. }\end{array}$ & $\begin{array}{l}\text { Don't reinvent the wheel, and/or } \\
\text { use questions that are not aligned } \\
\text { to your learning goals and your } \\
\text { exam. }\end{array}$ \\
\hline $\begin{array}{l}\text { Ensure that the particular } \\
\text { cognitive process necessary to get } \\
\text { to the correct answer mimics a } \\
\text { reasoning skill that is important } \\
\text { in your field, or to be a scientist in } \\
\text { general (e.g., deductive and } \\
\text { inference skills). }\end{array}$ & $\begin{array}{l}\text { Don't "give away" the correct } \\
\text { answer by placing it at the third } \\
\text { ("C") position and/or by having it } \\
\text { formulated differently than the } \\
\text { other answers. All answers } \\
\text { should look equally plausible to } \\
\text { the student. }\end{array}$ \\
\hline $\begin{array}{l}\text { Improve your clicker questions } \\
\text { before class by giving them to } \\
\text { colleagues, teaching assistants, } \\
\text { students in your lab, etc. Modify } \\
\text { your questions according to their } \\
\text { feedback. }\end{array}$ & $\begin{array}{l}\text { Don't be afraid to invent } \\
\text { questions on the spot, even by } \\
\text { writing them on the blackboard } \\
\text { and collecting votes using the } \\
\text { clicker software you normally use. }\end{array}$ \\
\hline
\end{tabular}




\section{During class}

As a start, aim to ask about $\mathbf{3 - 4}$
clicker questions to test for
conceptual understanding
during a $\mathbf{4 0 - 6 0}$ minute lecture.
Starting the lecture with a clicker
question can be a good warm up.
Ending with a clicker question also
helps with knowledge building
after a long lecture. Remember to
not lecture for more than 15
minutes before asking a clicker
question, as attention and
retention drop after that (CTL,
2005; Wieman, 2007).

When carrying out Peer Instruction, ask students after the first vote to "turn to someone who has a different answer than you and try to convince him of your answer". In doing so, you will enhance learning opportunities as you will increase the chances that students who have the correct reasoning will explain it to fellows who have not reached the same level of understanding yet. Luckily, students who vote correctly the first time are not very likely to get convinced to vote incorrectly the second time (Crouch, et al., 2007).

\section{Don't forget to space out your} clicker questions within a presentation. For example, there is no point to ask a recall question immediately after presenting those facts. You might want to keep lecturing and bring up that question later, to test retention or better, the application of a new concept to a broader situation.

\section{Don't show a clicker question} without first reminding students to not discuss with their neighbor. You can effectively do so by inserting a slide right before your clicker question, which says "Please answer the following question on your own". Failure to remind your students to not discuss might be interpreted as a signal that they should start discussing as soon as you pop up your question. If that happens, you can forget about Peer Instruction... 


Walk around the classroom
during peer discussion
(Yahanpath \& Yahanpath, 2012) in
order to ensure students
conversations are on track, and to
pick up correct but also faulty
reasoning (James \& Willoughby,
2011). In large classes, ask your
teaching assistants to help listen to
what the students are discussing
in the parts of the auditorium you
cannot reach. Circulating among
students and communicating with
them will help you organize the
follow up class discussion, will
give you ideas on how to phrase
your questions better (Chasteen,
2011), and will make for a good
ice-breaker with your students!

Before resuming the lecture, always explain the correct answer clearly to students - by saying it, by repeating it when a student says it, by highlighting it on the slide, etc. Peer discussion and explanation from the lecturer are actually "synergistic in helping students" (Smith, Wood, Krauter, \& Knight, 2011).

\section{Don't always show the results of} a vote if you want students to vote again to the same question, as in Peer Instruction, because it could bias the process (Perez, et al., 2010); similarly, responses recorded via show of hands or colored cards could be biased because of the lack of anonymity.

\section{Don't explain again a topic when} $>90 \%$ of the students get the correct answer. Conversely, if $<50-60 \%$ get the correct answer, don't continue your lecture as planned, i.e. with even more advanced material when the scores to the clicker question indicate the foundations are not there for most of the class. Instead, always have a plan B: activities, alternative ways of explaining (visuals, movies, real-world animations, analogies), demonstrations, additional clicker questions, etc. 


\section{Explain to your students why they are using clickers in your class (SEI, 2009). Stress how clickers will help them learn better and get a higher grade on their exam. As pedagogies supported by clickers are relatively new, they are still quite unfamiliar to most students. Students might then be reluctant to accept them over traditional lecturing, especially when using clickers "requires more work" during class than sitting back and taking notes (Lambert, 2012).}

\section{Become better at managing discussions effectively in a large} audience. For example, invite students to share their reasoning for why they choose a particular answer, but without hinting at which one is the correct answer. Instead of telling "You are wrong" to a student who mis-reasoned, ask the other students whether they agree/disagree with that student and why.

\section{Don't use clickers to measure attendance or participation in} your lectures. Students would be quickly turned off by clickers after that, even if you'd also present conceptual clicker questions. Along that line, don't just use clickers because they are popular or trendy. Explore why your colleagues appreciate to use clickers and let such insights guide your own use of clickers.

Don't always carry out peer instruction and then ask a student to volunteer for why they chose the correct answer. This is equivalent to inviting the best student or the most outspoken student to speak, at the expense of the perhaps less smart or more introvert student who will not dare volunteering in front of peers. 


\section{Box 2}

Types of clicker questions with representative examples and associated characteristics.

\begin{tabular}{|c|c|c|}
\hline $\begin{array}{l}\text { What type of } \\
\text { question can } \\
\text { you write? }\end{array}$ & Examples & Characteristics \\
\hline $\begin{array}{l}\text { Poll } \\
\text { A question to } \\
\text { collect basic } \\
\text { information about } \\
\text { your audience on } \\
\text { specific aspects, } \\
\text { or their opinion } \\
\text { on a particular } \\
\text { issue. }\end{array}$ & $\begin{array}{l}\text { "Have you used clickers } \\
\text { before? Yes/No" } \\
\text { "Where do you come } \\
\text { from? } \\
\text { A. Northern Europe; B. } \\
\text { Western Europe; C. } \\
\text { Eastern Europe; D. } \\
\text { Southern Europe; F. Not } \\
\text { from Europe" } \\
\text { "Do you think viruses } \\
\text { are alive? Yes/No" } \\
\text { "Are you for the use of } \\
\text { genetically modified } \\
\text { organisms (GMOs) in } \\
\text { food production? A. Yes, } \\
\text { absolutely; B. Yes, but I } \\
\text { would like to know } \\
\text { from the label; C. I am } \\
\text { indifferent to this issue; } \\
\text { D. No, unless it is in } \\
\text { small and clearly } \\
\text { labeled amounts; E. } \\
\text { Absolutely not" }\end{array}$ & $\begin{array}{l}\text { helps you know more } \\
\text { about your audience } \\
\text { stimulates } \\
\text { discussion/debate } \\
\text { can be done "on the } \\
\text { fly" to engage the } \\
\text { audience } \\
\text { does not directly } \\
\text { promote learning }\end{array}$ \\
\hline
\end{tabular}

\footnotetext{
${ }^{4}$ More details and examples of types of clicker questions can be found for example in (Bruff, 2009), in this resource guide from joints Science Education Initiatives led by Carl Wieman (Wieman, et al., 2009), on the SERC portal for educators for specific examples of clicker questions (also known as 'ConcepTests') used in Geoscience (SERC, 2012), and in the database of the National Center for Case Study in Teaching in Science (NSF, 2012).
} 


\begin{tabular}{|c|c|c|}
\hline $\begin{array}{l}\text { What type of } \\
\text { question can } \\
\text { you write? }\end{array}$ & Examples & Characteristics \\
\hline $\begin{array}{l}\text { Recall } \\
\text { A question to } \\
\text { verify what your } \\
\text { students } \\
\text { remember - } \\
\text { from the past } 10 \\
\text { minutes/from the } \\
\text { previous } \\
\text { lecture/from the } \\
\text { reading } \\
\text { assignment. }\end{array}$ & $\begin{array}{l}\text { "Which of the following } \\
\text { is NOT a function of } \\
\text { lipids in the cell? A. } \\
\text { Structural component } \\
\text { of the cell; B. Energy } \\
\text { storage; C. Information } \\
\text { storage; D. Cell-cell } \\
\text { communication" } \\
\text { "What molecule is } \\
\text { shown on this picture? } \\
\text { A. An amino acid; B. A } \\
\text { nucleotide; C. A lipid; D. } \\
\text { A carbohydrate." }\end{array}$ & $\begin{array}{l}\text { helps you check } \\
\text { whether your students } \\
\text { are following your } \\
\text { lecture } \\
\text { can be created to ask } \\
\text { students to define, } \\
\text { identify, match, } \\
\text { recognize, indicate, } \\
\text { etc. which are of low- } \\
\text { medium levels in } \\
\text { classifications of } \\
\text { cognitive skills } \\
\text { (Handelsman et al., } \\
\text { 2004) } \\
\text { could motivate a } \\
\text { discussion about study } \\
\text { skills if the results } \\
\text { show they did not } \\
\text { remember } \\
\text { can be done "on the } \\
\text { fly" to engage the } \\
\text { audience } \\
\text { does not directly } \\
\text { promote learning }\end{array}$ \\
\hline
\end{tabular}




\begin{tabular}{|c|c|c|}
\hline $\begin{array}{l}\text { What type of } \\
\text { question can } \\
\text { you write? }\end{array}$ & Examples & Characteristics \\
\hline $\begin{array}{l}\text { Conceptual } \\
\text { Understanding } \\
\text { A question - or } \\
\text { often, a short } \\
\text { problem - to } \\
\text { assess whether } \\
\text { students } \\
\text { understand the } \\
\text { concept(s) } \\
\text { associated with } \\
\text { what they may } \\
\text { remember from } \\
\text { your lecture. }\end{array}$ & $\begin{array}{l}\text { "Your sister calls to tell } \\
\text { you she is pregnant } \\
\text { with twins. Which of the } \\
\text { following is most likely? } \\
\text { (assume they are not } \\
\text { identical twins) A. Twin } \\
\text { boys; B. Twin girls; C. } \\
\text { One boy and one girl; D. } \\
\text { All are equally likely" } \\
\text { "Adding hydrogen } \\
\text { atoms to the fatty acid } \\
\text { tails of a triglyceride } \\
\text { containing double } \\
\text { bonds (C=C) would: A. } \\
\text { Increase the } \\
\text { triglyceride's melting } \\
\text { temperature; B. } \\
\text { Decrease the } \\
\text { triglyceride's melting } \\
\text { temperature; C. Have no } \\
\text { effect on the } \\
\text { triglyceride's melting } \\
\text { temperature; D. I don't } \\
\text { have enough } \\
\text { information to say" }\end{array}$ & $\begin{array}{l}\text { confronts students } \\
\text { with what they know, } \\
\text { and whether they } \\
\text { know! } \\
\text { uncovers } \\
\text { misconceptions or } \\
\text { wrong reasoning } \\
\text { can be created to ask } \\
\text { students to apply, } \\
\text { interpret, analyze, } \\
\text { detect, determine, } \\
\text { differentiate, } \\
\text { distinguish, etc. which } \\
\text { are of medium levels } \\
\text { in classifications of } \\
\text { cognitive skills } \\
\text { (Handelsman et al., } \\
\text { 2004) } \\
\text { promotes beneficial } \\
\text { student-student and } \\
\text { student-instructor } \\
\text { discussions } \\
\text { promotes learning }\end{array}$ \\
\hline
\end{tabular}




\begin{tabular}{|c|c|c|}
\hline $\begin{array}{l}\text { What type of } \\
\text { question can } \\
\text { you write? }\end{array}$ & Examples & Characteristics \\
\hline $\begin{array}{l}\text { Open-Ended } \\
\text { A question that } \\
\text { requires critical } \\
\text { thinking but may } \\
\text { not have a single } \\
\text { correct answer, or } \\
\text { no correct answer } \\
\text { at all. }\end{array}$ & $\begin{array}{l}\text { "Which of the following } \\
\text { statements regarding } \\
\text { possible professional } \\
\text { behaviors do you most } \\
\text { agree with? A. It's OK } \\
\text { for a researcher to } \\
\text { borrow part of a text } \\
\text { from a published article } \\
\text { without citing the } \\
\text { original source; B. It's } \\
\text { OK for a researcher to } \\
\text { copy part of a text from } \\
\text { one of his own } \\
\text { published articles; C. It's } \\
\text { OK for a researcher to } \\
\text { use the ideas presented } \\
\text { orally at a conference } \\
\text { without citing the } \\
\text { original source; D. It's } \\
\text { OK for a researcher to } \\
\text { use the ideas or } \\
\text { arguments from a } \\
\text { manuscript he has read } \\
\text { in double-blind peer } \\
\text { review." } 5\end{array}$ & $\begin{array}{l}\text { stimulates } \\
\text { discussion/debate } \\
\text { raises awareness on } \\
\text { sensitive/ethical/qual } \\
\text { ity issues } \\
\text { uncovers } \\
\text { misconceptions or } \\
\text { wrong reasoning } \\
\text { can be created to ask } \\
\text { students to build, } \\
\text { compose, propose, } \\
\text { argue, estimate, } \\
\text { predict, rank, etc. } \\
\text { which are of high } \\
\text { levels in classifications } \\
\text { of cognitive skills } \\
\text { (Handelsman, et al., } \\
\text { 2004) } \\
\text { promotes beneficial } \\
\text { student-student and } \\
\text { student-instructor } \\
\text { discussions } \\
\text { promotes learning }\end{array}$ \\
\hline
\end{tabular}

5 Example provided by Henrik Krag Sørensen, Centre for Science Studies, Aarhus University, Denmark. 


\section{References}

Banting, N. (2011). \{Musing Mathematically\}: Polling in Math class.

Retrieved on Oct. 31, 2012, from

http://musingmathematically.blogspot.dk/2011/11/polling-in-mathclass.html

Beatty, I. D., Gerace, W. J., Leonard, W. J., \& Dufresne, R. J. (2006). Designing effective questions for classroom response system teaching. Am. J. Phys., 1,31-39.

Biggs, J. (2007). teaching according to how students learn Teaching for quality learning at university, Third edition (pp. 15-30). New York, USA: Society for Research into Higher Education \& Open University Press.

BL. (2012). Teaching with technology: Blended learning - University of Waterloo, Center for Teaching Excellence, UK. Retrieved on Oct. 31, 2012, from http://cte.uwaterloo.ca/teaching with technology/index.html?tab=1

Blog. (2008). Research Quest: Library Dusk - Choose Your Own Adventure Database Review. Retrieved on Oct. 31, 2012, from http://researchquest.blogspot.fr/2008/02/library-dusk-choose-yourown-adventure.html

Bransford, J. D., Brown, A. L., \& Cocking, R. R. (2000). How People Learn Brain, Mind, Experience, and School. Washington, D.C.: National Academy Press.

Brodersen, D. E. (2012). Active Learning during Theoretical Exercises Frontiers in Science Teaching, Aarhus University, Denmark http://vimeo.com/47437799.

Brodersen, D. E., Etzerodt, M., \& Rasmussen, J. T. (2012). Experiences from introduction of peer-to-peer teaching methods in Advanced Biochemistry E2010. Peer-to-Peer Sharing Platform. Retrieved from http://cse.au.dk/en/knowledge-exchange/p2p-sharingplatform/contribution/artikel/experiences-from-introduction-of-peerto-peer-teaching-methods-in-advanced-biochemistry-e2010/

Bruff, D. (2009). Teaching with classroom response systems. San Francisco: Jossey-Bass.

Bruff, D. (2010). Agile Learning: Going nonlinear in PowerPoint, Agile Teaching, and CYOA. Retrieved on Oct. 31, 2012, from http://derekbruff.org/?p=780

Buchs, C., Butera, F., Mugny, G., \& Darnon, C. (2004). Conflict elaboration and cognitive outcomes. Theory into Practice, 43(1), 23-30.

Cech, T., \& Kennedy, D. (2005). Doing more for Kate. Science, 310(5755), 1741-1741. 
Chasteen, S. (2011). The Active Class: Listening to student conversations during clicker questions: What you have not heard might surprise you! Retrieved on Oct. 31, 2012, from http://theactiveclass.com/2011/01/31/listening-to-studentconversations-during-clicker-questions-what-you-have-not-heardmight-surprise-you/

Coholan, K. (2011). Electronics in the classroom. The Gauntlet. Retrieved from http://www.thegauntlet.ca/story/electronics-classroom

Crouch, C. H., \& Mazur, E. (2000). Peer Instruction: Ten years of experience and results. Am. J. Phys., 69(9), 970-977.

Crouch, C. H., Watkins, J., Fagen, A. P., \& Mazur, E. (2007). Peer Instruction: Engaging Students One-on-One, All at Once. In E. F. Redish \& P. J. Cooney (Eds.), Research-Based Reform of University Physics (Vol. 1). College Park, MD: American Association of Physics Teachers.

CTL. (2005). Speaking of Teaching: How to create memorable lectures Center for Teaching and Learning, Stanford University, CA, USA. Speaking of teaching, , 1-6. Retrieved from http://www.stanford.edu/dept/CTL/cgibin/docs/newsletter/memorable lectures.pdf

CWSEI. (2009a). Cliker Resources - Carl Wieman Science Education Initiative, and Science Education Initiative, University of Colorado.

CWSEI. (2009b). SEI Clicker and Education Videos - Carl Wieman Science Education Initiative, and Science Education Initiative, University of Colorado http://www.cwsei.ubc.ca/resources/SEI video.html.

Dean, J. (2011). Digital News Test Kitchen: Smartphone User Survey - A glimpse into the mobile lives of college students. Retrieved on Oct. 31, 2012, from http://testkitchen.colorado.edu/projects/reports/smartphone/smartp hone-survey/

Dillenbourg, P. (1999). What do you mean by collaborative leraning? In P. Dillenbourg (Ed.), Collaborative-learning: Cognitive and Computational Approaches (pp. 1-19). Oxford: Elsevier.

Dillenbourg, P., Baker, M., Blaye, A., \& O'Malley, C. (1996). The evolution of research on collaborative learning. In E. Spada \& P. Reiman (Eds.), Learning in Humans and Machine: Towards an interdisciplinary learning science (pp. 189-211). Oxford: Elsevier.

Duncan, D. (2008). Tips for successful "clicker" use - Science Education Initiative, University of Colorado, USA. Retrieved on Oct. 31, 2012, from http://www.cwsei.ubc.ca/resources/files/Tips for Successful Clicker U se Duncan.pdf

Google. (2012). Google Drive. Retrieved on Oct. 30, 2012, from https://drive.google.com 
Handelsman, J., Ebert-May, D., Beichner, R., Bruns, P., Chang, A., DeHaan, R., et al. (2004). Education. Scientific teaching. [Research Support, Non-U.S. Gov't]. Science, 304(5670), 521-522.

Handelsman, J., Miller, S., \& Pfund, C. (2007). Scientific teaching. New York: W.H. Freeman and Co.

Hanford, E. (2012). Don't lecture me: Rethinking the way college students are taught: American Radio Works http://americanradioworks.publicradio.org/features/tomorrowscollege/lectures/rethinking-teaching.html.

Hestenes, D., Wells, M., \& Swackhamer, G. (1992). Force concept inventory. The Physics Teacher, 30, 141-158.

HM. (2012). Eric Mazur shows interactive teaching. Retrieved on Oct. 30, 2012, from http://youtu.be/wont2v LZ1E

Illeris, K. (2003). Towards a contemporary and comprehensive theory of learning. Int. J. of Lifelong Education, 22(4), 396-406.

James, M. C., \& Willoughby, S. (2011). Listening to student conversations during clicker questions: What you have not heard might surprise you! Am. J. Phys., 79(1), 123-132.

Jones, R. (2012). Strategies for reading comprehension: Think-Pair-Share. Retrieved on Oct. 30, 2012, from http://www.readingquest.org/strat/tps.html

Knight, J. K., \& Wood, W. B. (2005). Teaching more by lecturing less. [Evaluation Studies

Research Support, U.S. Gov't, Non-P.H.S.]. Cell biology education, 4(4), 298310.

Lambert, C. (2012). The twilight of the lecture. Harvard Magazine http://harvardmagazine.com/2012/03/twilight-of-the-lecture.

Lasry, N. (2008). Clickers or Flashcards: Is There Really a Difference? The Physics Teacher, 46, 242-244.

Lasry, N., Mazur, E., \& Watkins, J. (2008). Peer instruction: From Harvard to community colleges. Am. J. Phys., 76(11), 1066-1069.

LC. (2012). What's new in Learning Catalytics? Retrieved on Oct. 31, 2012, from

http://learningcatalytics.uservoice.com/knowledgebase/articles/1058 69-what-s-new-in-learning-catalytics-

Levesque, A. A. (2011). Using Clickers to Facilitate Development of Problem-Solving Skills. Cbe-Life Sciences Education, 10(4), 406-417.

Lukoff, B. (2012). Turn to your neighbor: How do I get started with Peer Instruction? Part 1. Retrieved on Oct. 31, 2012, from 
http://blog.peerinstruction.net/2012/07/10/how-do-i-get-startedwith-peer-instruction-part-1/

Lyman, F. (1981). The responsive classroom discussion: The inclusion of all students. In A. S. Anderson (Ed.), Mainstreaming Digest (pp. 109-113): College Park: University of Maryland.

Machielse, C. (2011). How to get the best results with Lecture Tools. Lecture Tools User Blog. Retrieved from http://info.lecturetools.com/user-blog/bid/39656/How-to-Get-theBest-Results-with-LectureTools

Mazur, E. (1997). Peer Instruction: A user's manual. Upper Saddle River, NJ, USA: Prentice Hall Inc.

Mazur, E. (2008). From Questions to Concepts: Interactive Teaching in Physics, Derek Bok Center for Teaching and Learning, Harvard University. Retrieved on Oct. 30, 2012, from http://youtu.be/lBYrKPoVFwg

Mazur, E. (2011). Turning lectures into learning, Turning Technologies Users Conference, University of Surrey, UK. Retrieved on Oct. 30, 2012, from https://http://www.youtube.com/watch?v=2JEUsTTQG0M\&list=PL782 6727AC8A9436C\&index=1\&feature=plpp video

Mazur, E. (2012). Catalyzing learning using Peer Instruction and Learning Catalytics - Université de Lausanne, Switzerland. Retrieved on Nov. 5, 2012, from http://youtu.be/bdor83ZVgEc

Mazur, E., King, G., \& Lukoff, B. (2011). Learning Catalytics: The complete solution for managing the interactive classroom. Retrieved on Oct. 31, 2012, from https://learningcatalytics.com/

Mazur, E., \& Watkins, J. (2009). Just-in-Time Teaching and Peer Instruction. In S. Simkins, M. Maier \& J. Rhem (Eds.), Just in Time Teaching: Across the Disciplines, and Across the Academy (pp. 39-62). Sterling, VA: Stylus Publishing, LLC.

Mull, B. (2009). An educator's introduction to Poll Everywhere http://youtu.be/zZWM2-4Jf4k.

NSF. (2012). National Center for case study in teaching science - National Science Foundation. Retrieved on Oct. 31, 2012, from http://sciencecases.lib.buffalo.edu/cs/results.asp?search=clicker\&Sub mit. $x=0 \&$ Submit. $y=0$

Perez, K. E., Strauss, E. A., Downey, N., Galbraith, A., Jeanne, R., \& Cooper, S. (2010). Does Displaying the Class Results Affect Student Discussion during Peer Instruction? Cbe-Life Sciences Education, 9(2), 133-140.

Prather, E., Slater, T., Brissenden, G., \& Forestell, A. (2008). Revisiting Think-Pair-Share: An expanded "how-to" guide - California Institute of Technology, Center for Astronomy Education. Retrieved on Oct. 31, 
2012, from

http://astronomy101.jpl.nasa.gov/teachingstrategies/teachingdetails/? $\underline{\text { StrategyID }=23}$

RU. (2011). HR Class participation peaks through Professor Methot's polling - Rutgers University, School of Management and Labor Relations, NJ. USA. Retrieved from http://smlr.rutgers.edu/news-events/hr-classparticipation-peaks-through-professor-methot\%E2\%80\%99s-polling

Samson, P. (2012). Lecture Tools. Retrieved on Oct. 31, 2012, from http://www.lecturetools.com/

Schell, J. (2012). Turn to your neighbor: How to write and evaluate effective questions: Best Practices in Peer Instruction. Retrieved on Oct. 31, 2012, from http://blog.peerinstruction.net/2012/05/05/how-to-writeand-evaluate-effective-questions-best-practices-in-peer-instruction/

SEI. (2009). Explaining to your students why you're using clickers - The Science Education Initiative, University of Colorado, USA http://youtu.be/NGx7EzDQ-lY.

SERC. (2012). Pedagogy in Action: ConcepTest examples - National Science Digital Library, USA. Retrieved on Oct. 31, 2012, from http://serc.carleton.edu/sp/service/index.html

Smith, M. K., Trujillo, C., \& Su, T. T. (2011). The benefits of using clickers in small-enrollment seminar-style biology courses. [Research Support, Non-U.S. Gov't]. CBE life sciences education, 10(1), 14-17.

Smith, M. K., Wood, W. B., Adams, W. K., Wieman, C., Knight, J. K., Guild, N., et al. (2009). Why peer discussion improves student performance on inclass concept questions. [Research Support, Non-U.S. Gov't]. Science, 323(5910), 122-124.

Smith, M. K., Wood, W. B., Krauter, K., \& Knight, J. K. (2011). Combining Peer Discussion with Instructor Explanation Increases Student Learning from In-Class Concept Questions. Cbe-Life Sciences Education, 10(1), 55-63.

SML. (2010). The use of clickers in science teaching at Aarhus University Science Media Lab at the Center for Science Education http://vimeo.com/18964579.

Socrative. (2012). Socrative: As easy as raising your hand. Retrieved on Oct. 31, 2012, from http://www.socrative.com/how-it-works.php

Somlai-Fischer, A., Halacsy, P., \& Arvai, P. (2009). Prezi, a cloud-based presentation software. Retrieved on Oct. 30, 2012, from http://prezi.com/

Steinberg, J. (2010). More professors give out hand-held devices to monitor students and engage them. The New York Times. Retrieved from http://www.nytimes.com/2010/11/16/education/16clickers.html 
Suskie, L. (2009). Writing a Traditional Test Assessing Student Learning: A Common Sense Guide, Second Edition (pp. 165-182). San Francisco: Jossey-Bass.

TT. (2011a). ResponseWare. Retrieved on Oct. 31, 2012, from http://www.turningtechnologies.com/studentresponsesystems/mobile distancelearning/higheredresponseware/

TT. (2011b). Turning Technologies User Conference - University of Surrey. Retrieved on Oct. 30, 2012, from https://http://www.youtube.com/playlist?list=PL7826727AC8A9436C

Tyler, R. W. (1949). Basic Principles of Curriculum and Instruction. Chicago and London: The University of Chicago Press.

UN. (2010). The University of Navarra has introduced "clickers" as a teaching tool. Retrieved on Oct. 30, 2012, from http://www.unav.es/english/news/300310.html

Vicens, Q. (2010). The Broken Dam: Smart use of technologies to support better teaching. Retrieved on Oct. 31, 2012, from http://thebrokendam.com/tag/clickers/

Wieman, C. (2007). Why not try a scientific approach to science education? Change, 39(5).

Wieman, C., Perkins, K., Gilbert, S., Benay, F., Kennedy, S., Semsar, K., et al. (2009). Clicker resource guide - Carl Wieman Science Education Initiative and The Science Education Initiative at the University of Colorado. Retrieved from http://www.cwsei.ubc.ca/resources/files/Clicker guide CWSEI CUSEI.pdf

Wikipedia. (2012). Wikipedia: PageRank. Retrieved on Oct. 31, 2012, from http://en.wikipedia.org/wiki/PageRank

Wiley, C. (2012). Educational Vignettes: Personal Response Systems: Review of the Turning Technologies User Conference 2012, Aarhus University, Denmark. Retrieved on Oct. 31, 2012, from http://educationalvignettes.wordpress.com/2012/08/17/personalresponse-systems-review-of-the-turning-technologies-user-conference2012-aarhus-university-denmark/

Yahanpath, S. P., \& Yahanpath, S. (2012, Oct. 3, 2012). Power of 'Teaching By Walking Around'. Daily FT. Retrieved from http://www.ft.lk/2012/10/03/power-of-teaching-by-walking-around/ 